ARTICLE

https://doi.org/10.1057/s41599-019-0332-8

\title{
OPEN
}

\section{Comparative analysis of rural poverty and inequality in the UK and the US}

\author{
Ruth McAreavey ${ }^{1 \star} \&$ David L. Brown ${ }^{2}$
}

\begin{abstract}
Scholars on both sides of the Atlantic have grappled with the difficulties of conducting comparative research on rural issues in general, and on rural poverty and inequality in particular. Shortall and Warner have observed that "The UK-US dialog is highly illustrative of how seemingly similar situations turn out to be full of complexity and difference." That complexity and difference can serve to turn researchers away from comparative collaborations. We begin our paper with an overview of some of the general differences (and similarities) between how rural scholars in the UK and US have examined poverty and inequality in rural areas. Analysis of the two welfare regimes in these countries provides the backdrop for examining specific aspects of deprivation for rural people and communities. Our paper draws on our experience as members of a trans-Atlantic research group to illustrate the type of organisational infrastructure that can support international, interdisciplinary collaboration. We conclude by offering suggestions for future comparative research. Our paper progresses earlier debates in rural studies on the challenges of doing comparative USUK analysis.
\end{abstract}

\footnotetext{
${ }^{1}$ Sociology Newcastle University, Newcastle NE1 7RU, UK. ${ }^{2}$ Department of Development Sociology, Cornell University, Cornell, NY 14850, USA.

*email: Ruth.mcareavey@newcastle.ac.uk
} 


\section{Introduction}

cholars on both sides of the Atlantic have grappled with the difficulties of conducting comparative research on rural issues in general, and on rural poverty and inequality in particular. Issues of scale, definition, culture, and language vary across nations, as do their respective regulatory structures and welfare regimes (Shucksmith and Schafft, 2012; Shucksmith and Brown, 2016). Making the situation even more difficult, the two nations differ in how they conceptualise rural and rurality (Shucksmith and Brown, 2016). As Shortall and Warner (2012, p. 5) observed, "The UK-US dialog is highly illustrative of how seemingly similar situations turn out to be full of complexity and difference." As a result, many rural studies scholars have concluded that these differences make a methodologically harmonised comparative analysis of rural poverty and inequality in the US and UK extremely challenging, if not impossible ${ }^{1}$. This is an important gap in the 21 st century as it curtails knowledge exchange between two of the largest global economies.

Backing away from methodologically harmonised comparative analysis seems to us less than satisfying, yet we cannot deny that knowledge is rooted in the experiences and structures of particular nation states at particular times. Hence, rather than aspiring to an impossible goal, this paper on rural poverty and inequality in the UK and US is shaped by the concept of "pluralistic universalism" as developed by the Gulbenkian Commission on the Restructuring of the Social Sciences (Wallerstein, 1996). Therefore, while methodologically harmonised comparative analysis might be problematic, we contend that the UK and US can be placed in parallel in order to gain evidence-based insights about the structural forces that produce and reproduce poverty and inequality in rural areas of the respective nations, as well as policies to ameliorate these problematic conditions (Lowe, 2012). We also contend that this type of comparative analysis can be supported by an organisational infrastructure of international and interdisciplinary collaboration.

We begin our paper with an overview of some of the general differences (and similarities) between how rural scholars in the UK and US have examined poverty and inequality in rural areas. This includes an in-depth analysis of the concepts and their application. Next, we consider the welfare regimes in the two nations as a means of setting important context, including noteworthy aspects of deprivation that are specific to rural people and communities. We then recommend areas where we believe comparative research on rural poverty and inequality would be productive going forward. In so doing our paper progresses earlier debates in rural studies on the challenges of doing comparative US-UK analysis (Shucksmith et al., 2012).

Examining poverty and inequality in the US and UK. Poverty and inequality are often conflated, but they are not the same. In both instances, these two concepts are typically thought of as a lack of access to material resources, usually indexed by a lack of income. However, poverty can be high in places with an even distribution of income, and vice versa. For example, Mather and Jarosz (2016) found that $12 \%$ of US counties had high poverty rates but low levels of income inequality, and $18 \%$ of counties had high income inequality and low rates of poverty ${ }^{2}$.

Poverty is typically defined as a lack of material resources necessary to live a decent life. Poverty can be examined as an individual (or household) attribute, or it can be seen as a population characteristic, e.g., a population can have a high or low poverty rate. Inequality, in contrast, is solely a population characteristic. People can be poor or rich, but they cannot be unequal. Moreover, while poverty and social inequality often refer to income, they can also focus on multiple domains of disparity such as access to health care, education, housing, well-paying jobs, etc. Both poverty and inequality, especially as examined at the population level, focus on access to material resources in society's various institutional domains, and the degree to which an individual is able to maximise his or her potential as compared to others in society ${ }^{3}$ (Binelli et al., 2015). This raises a myriad of issues relating to power relations and influencing rights, privileges and public goods, all of which are beyond the scope of this paper, but nonetheless vary across the US and UK and are among the determinants of variability in poverty and inequality.

Income inequality is a measure of how unequally income is distributed throughout a population, or operationally, how many households (or individuals) would have to move up (or down) in the distribution so that all households had the same income. Inequality is measured in the same way in the US and UK. The Gini or the Thiel Coefficient (Allison, 1978) are the usual measures, although some analysts employ other measures such as entropy (Gray, 2011). Income inequality intersects with the concept of poverty because both have low income at their core, but as stated above high poverty can exist in the context of low inequality and vice versa. While individuals or households cannot be said to be equal or unequal, they can, and do live in places with different levels of inequality, and this can affect their well-being and their life course trajectory.

Poverty can be measured/conceptualised as either an absolute measure, e.g., failure to achieve a certain baseline level of material resources, or as a relative measure, e.g., where household or personal income is compared to a particular point in a nation's, or community's, income distribution, for example, having an income below $60 \%$ of the national median income (Chapman et al., 1998; Lister, 2004). From a conventional statistical standpoint, these concepts and measures do not vary significantly between the UK and US, except that the US is more likely to employ absolute poverty while the UK (and most of the EU) uses relative poverty (Shucksmith and Schafft, 2012). In addition, European rural scholars have been important proponents of a broader, multi-dimensional conceptualisation of poverty, if not of inequality. This extends the analysis beyond income to wider relational issues including how a diverse range of resources such as education, housing, transport, etc. is distributed in society, who has entitlements and rights to these resources, and what constitutes public goods. This broader notion of poverty therefore relates to a disadvantaged and insecure economic condition in relation to other groups in society (Lister, 2004).

As indicated earlier, poverty can be examined at either the micro or macro level while inequality is a strictly macro-level phenomenon. In other words, one can examine why some people are more likely to be poor, to exit poverty, or to re-enter poverty, or one can examine why some kinds of places are more likely to have higher poverty rates than others or to persist as high poverty areas. In contrast, variability in the degree of inequality is a macro-level question in that one examines the determinants of inter-place variability in the degree of inequality, and changes therein over time. Macro analysis typically compares "ecological" units such as states, counties and places in the US or counties, local authorities or places in the UK. ${ }^{4}$

Income inequality is more similar in both concept and measurement to relative poverty than to absolute poverty because it is relational. As indicated above, inequality is a macro-level concept, a characteristic of a population. Accordingly, the empirical question focuses on explaining inter-area variability in the degree of income inequality. Such studies typically examine patterns within a nation state, encompassing the association of place characteristics such as economic structure and change, changes in demographic size and composition, the natural 
resource base or/and institutional capacity and the degree of inequality or the poverty rate. Such studies can be either cross sectional or longitudinal, but at least part of the explanation of why some places do better than others is the result of historical legacies of underdevelopment, deprivation, discrimination, rigid class boundaries, or/and resource exhaustion. This is very well illustrated in Chetty et al.'s (2018) study of intergenerational mobility in the United States. To explore the factors associated with upward mobility as measured by the income of children compared to their parents, they examine residential segregation, income inequalities, social capital and family stability. Their resulting "Opportunity Atlas" shows area differences in upward mobility across the United States.

Micro-level analysis of the determinants of the likelihood of poverty at the individual or household level typically examines the role of ascribed characteristics, age, sex, ethnic background, etc. and achieved characteristics, educational attainment, work experience, etc. on the chances of being poor, and of poverty dynamics, e.g., becoming poor, escaping poverty (Barnard et al., 2018, Chapman et al., 1998, Rank and Hirschl., 1999, Stevens., 1999). However, Chetty's work makes it clear that the determinants of poverty operate at multiple levels. Clearly, where one lives affects one's life chances. Hence, the impact of living in particular types of places in addition to personal and household characteristics like education, age, sex, employment status, migration status each effect a person's (household's) likelihood of being poor. In the UK there has been a tendency to fragment the concept of poverty. Consequently, we see reference to "fuel poverty" (Middlemiss, 2017) 'food poverty' (Lambie-Mumford, 2015, Purdam et al., 2016) and "holiday hunger". Sectioning poverty in this way can distract attention from the fundamental causes of poverty, i.e., precarious employment and high levels of in-work poverty, the retreat of the state and the reduction of essential services. Poverty research in the US has not examined "fragmentation" as in the UK.

As indicated above, poverty and inequality should not be conflated, but this is not to say that they do not interact. While people do not have a high or low degree of income inequality, they reside in places with varying degrees of inequality. Accordingly, living in a place with high, or low, income inequality is among the contextual factors that could hypothetically affect a person's likelihood of being poor or well off. In other words, the characteristics of one's place of residence are seen as contextual predictors of personal or household level well-being. This connects back to lack of access to certain resources that we identify above. The empirical project here is to establish the impact of place of residence on individual and household-level outcomes such as being or becoming poor, or exiting poverty. Research seldom engages with this multi-level question in either the US or UK.

In addition to the somewhat different conceptual approaches to poverty and inequality described above, US and European studies are thought to differ in methodological approach. US studies are seen as more likely to be quantitative while European and UK research is thought to be more likely to be qualitative. This difference, however, is exaggerated. In truth, there are many examples of both approaches in the UK and US. Chapman and her associates (1998), for example, conducted a strong set of quantitative studies of the dynamics of low income and employment in Britain using data from the British Household Panel Study. More recently, Vera-Toscano et al., (2019) used the BHPS to examine the impact of New Labour's 1997 reforms on UK poverty dynamics in both urban and rural areas. In the US, where quantitative analysis is more prevalent, Fitchen (1991), Sherman (2009), Carr and Kefalas (2009), Duncan (2014) and others have conducted deep, grounded studies of US rural poverty. Moreover, the current direction in research design in both countries is to conduct mixed methods studies that merge quantitative and qualitative research methodologies. Even so, conducting comparative research across these distinct contexts can be challenging.

Different models for understanding rural social inequalities in the US and the UK involve debates on space, place, social groups and demography. Consequently, quality of life indicators across a range of domains are frequently used by researchers to evaluate inequalities including income, but also housing, access to amenities, social and family networks, health, life-expectancy and well-being, along with individual perceptions of these categories (see for instance Duncan and Lamborghini, 1994; Mathieson et al., 2008; Shucksmith et al., 2009; Smith et al., 2010; Tsimbos et al., 2014; Monnat and Rigg, 2016). But how precisely does this differ between the US and UK?

For one, a lot of UK research on inequality is less empirical than US research. As Shucksmith (2012) observes, UK scholars often discuss inequality and social exclusion but without supporting these observations with empirical data. Regardless of the empirical basis, the assumption is that rural areas in the UK are deprived and suffer inequality in some way. This assumption is called into question by Shucksmith et al. (2009) whose research in the richest EU countries shows minimal urban-rural differences across numerous life domains including housing, employment, educational achievement and subjective well-being.

In contrast, research in the US, while typically limited to examining income inequality or poverty, and not examining other forms of exclusion, consistently presents evidence-based analysis of persistent rural disadvantage (President's National Advisory Commission On Rural Poverty, 1967; Sherman, 2014; Shucksmith and Schafft, 2012). The establishment of the Task Force on Persistent Poverty in Rural America by the Rural Sociological Society in 1993 illuminated the plight of marginalised rural communities and groups. The Task Force rejected simplistic understandings of rural poverty as a consequence of individual lifestyle, and balanced this individualistic position with evidence of a lack of jobs, a mismatch between skills and available jobs, and historical legacies of underdevelopment, and rigid class structures that prevent social mobility (Rural Sociological Society, 1993). Interestingly, recent research by Thiede et al. (2019) indicates that rural-urban differences in inequality are narrowing because of an increase of urban inequality while rural inequality has stayed about the same. Moreover, when the contributions of in-kind income and the economic value of social programmes are considered, rural-urban differences in poverty disappear in the US (Nolan et al., 2017).

Different welfare regimes: a context for comparing poverty and inequality in the UK and the US. Welfare states are key features of OECD countries including the UK and US and they greatly impact on individual and community level wellbeing, affecting individual experiences of poverty and influencing inequalities in particular places. According to Therborn (1984), a welfare state relates to public expenditure and public employment and is one where significant government spending is on social policy (as opposed to defence, military, economy, law and order). Both the US and the UK are liberal welfare states according to EspingAnderson's definition, largely meaning that the market is central and the state marginal to welfare provision. Although the UK and US welfare regimes share some fundamental similarities, UK-US differences are significant. Accordingly, while structural impediments to access to services, such as geographic remoteness, population size, and adequate transport limit access to programme benefits in both countries, rural persons have generally 
greater access in the UK compared with the US. This is because the UK's centralised system is more organisationally uniform across the nation, assuring more geographic equality. In the US, in contrast, many programmes are devolved to the states giving them more flexibility in eligibility and programme delivery. Since states differ in their attitudes toward social welfare this results in differences in the stringency of eligibility criteria and programme generosity. Moreover, there can be variability in programme generosity across geographic scales within particular states. With these differences in mind, we describe basic elements of the UK and US social welfare systems, and how they might affect rural people and communities.

The UK welfare state. In the UK, the welfare state was formed in the wake of the Second World War. Beveridge (1942) identified five key "giant evils" that would be addressed by a welfare state: want, disease, ignorance, squalor and idleness. Ideology was an important driver for the creation of this modern UK welfare state, with Atlee's government leading a post-war consensus driven by Keynesian policies. This included an enlarged system of social services premised around the three pillars of rights, redistribution and regulation. That agenda was very much about equality of outcome, ensuring wealth redistribution and achieving minimum standards of living, as measured across a range of domains including housing and health. Progressive and regressive policies are used to achieve fundamental social objectives (Gough, 2008).

The challenge of monetarism in the 1970s heralded a disruption to the harmony between economy and social policy (Mishra, 1984, Gough, 2008). Subsequently, under Thatcher's reign during the 1980s, the dismantling of the post-war welfare regime became even more heightened. This resulted in an increased role for the community and voluntary sector, and a reduction of public expenditure. In 1996, the Conservative government instituted Income Support with Job Seekers Allowance (JSA). This policy incentivized work, applied job search requirements, and reduced benefit levels. Still, the UK's poverty rates stood at about 25 pct. in 1997 when the Labour Government took over. In fact, a third of all the poor children in the EU15 countries were born in the UK at this time (Toynbee and Walker, 2011).

The New Labour government fundamentally transformed the UK's social welfare policies which dramatically reduced poverty throughout the nation (Vera-Toscano et al., 2019). Together with the growing economy after 2000, New Labour's polices were associated with a fall in the numbers of JSA claimants by $16.5 \%$ across England during 2000-06, and in rural England by $27 \%$ (Department for Work and Pensions DWP 2007). This new policy regime included a suite of programmes that continued the 'welfare to work' approach begun by the Conservatives and deployed by the Clinton government in the US. However, Labour governments from 1997 more than offset these contingencies with more generous measures 'to make work pay', thereby in both respects increasing incentives to work (Brewer and Shepherd, 2004; Cappellari and Jenkins, 2014). New Labour's suite of reforms shifted support from benefits to tax credits, and from the Department of Work and Pensions to Her Majesty's Revenue and Customs. The policies offered more generous in-work support for low-income families and for pensioners. ${ }^{5}$

Moreover, New Labour promoted the notion of the 'Third Way', and in so doing created an enhanced role for the voluntary sector in welfare provision, something that continued under the Coalition Government's 'Big Society' during 2010-2015 (Cabinet Office, 2010). The rhetoric was about 'opening up public services' so that local communities could identify priorities for their area and become empowered to take action (Woodhouse, 2015, p. 3). Civil society has been playing a critical role in this current age of welfare reform, possibly not in the way that the Conservative government envisaged within their vision of 'Shared Society'. They get involved in many ways including advocating on behalf of recipients, supporting them if payments are delayed and setting up support structures to counter the 'insidious brutality' accompanying Universal Credit (Cheetham et al., 2019).

Today the UK government has rowed back somewhat with its vision of a 'Shared Society' where government fully supports free markets, but wants also to encourage and strengthen the work of civil society (May, 2017). Deep cuts to public expenditure have resulted (O'Hara, 2015). The rolling out of Universal Credit, meanwhile has created manifold problems with a disproportionate impact on individuals with complex mental and physical health needs, and it has led to a marked increase in the number of food banks in areas where the scheme was piloted (Hickman et al., 2017). The combined impact of welfare reforms and cuts in public sector spending has a greater impact on poorer households and households with disabilities (Reed and Portes, 2018). However, there is as yet no evidence that these retrenchments have had a disproportionately negative impact on low income persons living in rural areas in comparison with their urban counterparts.

The US welfare state. While both the UK and US systems embody the fundamental "welfare to work" principle, the US welfare state places much more focus on market solutions, and individual responsibility. Temporary Assistance to Needy Families (TANF) is the only US cash welfare programme. As the name implies, TANF benefits are temporary (up to 3 years). Moreover, eligibility is contingent on a claimant being employed, seeking employment, or being in job training. The work incentive embedded in TANF is further enunciated in the Earned Income Tax Credit which enhances the value of wages and salaries. In addition to TANF and the Earned Income Tax Credit) (EITC), low income Americans can be eligible for a number of in-kind programmes including SNAP (food stamps), Low Income Home Energy Assistance, Housing Assistance, among others ${ }^{6}$.

In addition, since the US has a federalist political economy, the central government is relatively weak in the realm of social policy. Accordingly, there is quite a bit of variability of coverage among individual states. New York spends the greatest per capita amount at $\$ 3305$ in 2016 compared with $\$ 1139$ by Georgia (Urban Institute, 2019). On average, state and local governments spent $\$ 1972$ per capita on public welfare in 2016. Much of this money is passed through from the national government via block grants, and then distributed to localities. In addition, some of this expenditure is resourced with local taxes and fees. Eligibility of this range of programmes, especially if funding originates at the national level, is determined according to federal rules. However, within these rules, states have some discretion in determining eligibility. States also have varying rates of take-up of public welfare programmes among eligible populations. Take-up rates vary across states reflecting individual and family decisions to apply and/or state-level actions that make it easier or more difficult for people to access benefits (Urban Institute, 2019).

While the US constitution provides equal protection under the law, it does not guarantee equal opportunity. In each realm of social policy whether it be income maintenance, food security, health care, or education, the national government is subordinated to the 50 states, and the expectations for government assistance, from any level of government, are lower than in the UK. Moreover, as indicated above the generosity of social welfare systems varies significantly across the 50 states. The one exception is retirement security where older Americans can expect the same benefit levels regardless of where they live, and to a great extent the amount of income they earned during their 
work lives. However, the Social Security benefit level is quite modest and older adults who can afford to do so merge Social Security with pensions and personal investments. Over the years these latter sources of retirement income have largely transitioned from defined benefit to defined contribution. In 2015, AARP estimates that about one quarter of Americans age 65+ depend on Social Security for $90 \%$ or more of their income. This, of course, increases the possibilities of significant income inequality within the older population since persons with additional sources of income are much better off.

At the present time, the states pay for a share of the cost of public pension plans, unemployment insurance, education, Medicaid, and the Temporary Assistance for Needy Families program (TANF), among other benefits. However, while most states fund many of these social programmes, the amounts and levels they spend vary widely. For example, Rhode Island was ranked as the top-spending state while Tennessee is the lowest ranked (Sauter et al., 2014). In Tennessee a single parent family of three that depended solely on TANF for cash could receive just $\$ 185$ per week in TANF benefits, and the ratio of TANF to the poverty level was just $23 \%$. Even when in-kind benefits such as food stamps are added, such a family would receive benefits equal to less than half of the poverty level. As of 2012, $17.9 \%$ of Tennessee's residents lived below the poverty line, versus $15.9 \%$ of all Americans (24/7 Wall Street 2014). In Rhode Island, in contrast, monthly TANF benefits were $\$ 554$, and the ratio of TANF to the poverty level was $36 \%$ (Centre for Budget Priorities, 2017).

Deprivation specific to rural people and communities. While poverty and deprivation exist throughout a nation, some aspects are more likely to affect rural people and communities than their urban counterparts. This is because certain demographic groups who are more likely to live in rural areas are more at risk of poverty, for example the elderly, farm workers, low income factory workers. Certain types of rural industries such as low skill manufacturing may be more vulnerable in "off-shoring", and rural institutions may have less fiscal and professional capacity to deliver social welfare programmes. With this general observation in mind, we examine aspects of rural deprivation that have been subject to significant debate in the rural studies arena and are more likely to be found in the UK compared with the US, or vice versa.

Social exclusion and rural poverty. European and UK scholars and their US counterparts deploy a relatively similar conceptual framework when examining poverty and inequality. In contrast, the analysis of "social exclusion" tends to be a European intellectual project (Byrne, 1999) with the concept appearing widely in the literature (see for instance Byrne, 1999; Sibley, 1995; Shucksmith et al., 1993; Bock et al., 2014; Milbourne, 2004, Mathieson et al., 2008). Importantly this focus on exclusion has shaped the EU rural development programme.

Modern conceptions of social exclusion were introduced by René Lenoir in an attempt to promote social cohesion and to reverse exclusion (Mathieson et al., 2008). The state was central to this endeavour. Part of the reason for the move away from a discourse of absolute poverty to one of social exclusion within the EU was that it shifted emphasis from individual failings to a focus on other measures of consumption, and on the roles of structural impediments and historical legacies in constraining access to work and opportunity (Nolan and Whelan, 2007; Platt, 2007; Bock et al., 2014). A social exclusion perspective considers the poor to include persons, families and groups whose resources (material, cultural and social) are so limited as to exclude them from the minimum acceptable way of life of the member state to which they belong. Furthermore, social exclusion requires intentionality, not simply having less opportunity because one resides in a low resource community. Excluded groups are barred, kept out, banned, or prohibited from fully participating in one or more of society's institutions, be it education, work, housing, civic engagement because other groups benefit from their exclusion.

Hence, Platt (2007) notes that while income poverty, deprivation, inequality and social exclusion are often used interchangeably, they are fundamentally different but related ideas with low incomes at the core, encompassing people's standard of living and the ability to adequately participate in society. An explicit emphasis on social exclusion is not found in the US rural literature (Shucksmith and Schafft, 2012; Moffatt and Glasgow, 2009). It is not that US researchers are not concerned with lack of access to these resources, but more a case that they do not consider such deficits as comprising aspects of poverty. While one may think that this is fundamentally short sighted of the Americans, in fact, research seldom examines the extent to which housing, healthcare, transport and other domains of inequality are contingent on a relative lack of income among excluded individuals and households, or whether other dynamics also limit access to essential resources in particular types of communities. In some rural communities in both the US and UK, limited access is thought to extend beyond a lack of income and be associated with inadequate capacity of public institutions, exclusionary social relationships, poor infrastructure, ineffective public policies, and a lack of control of natural resources (Shortall and Brown, 2019). Accordingly, while not specifically identified as "social exclusion", rural scholars in the US have examined how institutional structures and legacies constrain life trajectories and well-being in rural communities. Studies focused on areas of entrenched deprivation, such as Appalachia and the Mississippi Delta, are cases in point (Duncan, 2014; Carr and Kefalas, 2009, Fitchen, 1991).

There appears to be consensus between European and US scholars that spatial and socioeconomic contexts are important for highlighting the interplay between regional and local circumstances along with family and individual factors, all of which interact to influence rural economic pathways (see for instance Jensen, 1994; Milbourne, 2004; Shucksmith et al., 2009). In other words, in addition to one's personal characteristics, a person's likelihood of being poor or otherwise disadvantaged may be influenced by residence in places with social structures that constrain upward mobility by poor persons or persons with particular demographic characteristics. Places vary with respect to a number of conditions that influence how income (and other resources) are distributed, including the rigidity of social hierarchies, the capacity of local institutions to provide education and health care, industrial-occupational structure, and other labour market institutions that affect equal employment opportunity and equitable returns to work (Duncan, 2014; Lobao et al., 2007; Van Heuvelen, 2018).

Migration and rural poverty. Rural areas in both the UK and US have been the destination of increasing numbers of migrants, both international and internal, many of whom exist in the margins of society, experiencing poverty and hardship. Accordingly, an examination of the fate of rural in-migrants is key to understanding one dimension of poverty and inequality in rural destinations. Because migration is selective of particular demographic and economic groups, its population-level impact on a destination's poverty rate or degree of inequality is also important to know. A growing body of research has identified the plight of migrants in the UK and US rural economies (see for instance Lichter and Johnson, 2006 McConnell and Miraftab, 2009; 
McAreavey, 2017b, Findlay and McCollum, 2013, Doyle, 2018). Research shows that many migrants in the rural UK are disproportionately represented in jobs with little security that are often rejected by local people and include work in agriculture, horticulture, food processing, small industries and social care. Migrants working in these sectors face discrimination including harassment, differential treatment such as being paid less to undertake the same work or unequal access to employment rights. Their housing is typically of a low quality, with many living in houses of multiple occupancy or tied to their employment and as a result many live in constant fear of losing their job and becoming destitute (McAreavey, 2017a). As a result, many of these migrants are excluded from the mainstream, in short they have a precarious existence. Being denied membership in the mainstream in this way can violate individual self-respect and dignity, and it can be disruptive of rural society (Fahey, 2010; McAreavey, 2019).

The situation of migrants in the rural US is largely similar, although their marginality is further compounded by a lack of legal status among undocumented international migrants. Another difference is that while most rural in-migrants in the UK come from abroad, a higher percentage of rural in-migrants in the US come from elsewhere in the US (Johnson and Lichter, 2016, USDA, 2018). Some of these people have been in the US for a considerable time, some are onward migrants of more recent entry to the US (Kritz et al., 2013). In the US, rural immigrants most often work in agriculture, food processing and construction (Kandel and Parrado, 2006). As described by De Lima, et al. (2012) rural immigrants are highly segregated from host populations in both the US and UK. In fact, as Pfeffer and Parra (2009) have described, it is as though they are living in "separate societies", a matter reinforced more recently by Moore's (2019) study of Eastern European migrants living in rural England (see also Lichter et al., 2018).

Regardless whether rural migration occurs in the US or UK, migrants are exposed to a high degree of marginality and exploitation. In the US, this is reinforced by their lack of legal status, and lack of English language proficiency. Interestingly, research in the UK shows that having legal residence is no guarantee against discrimination and exploitation of migrant workers (McAreavey, 2017b). This vulnerability appears to be heightened in the era of Brexit where extreme nationalism and xenophobia are on the rise. The same is not true in Scotland where migrants are welcomed, and encouraged to stay permanently (Kyambi et al., 2018).

While this discussion seems to paint a clear picture of exclusion and marginalisation, it should also be noted that it belies micro-encounters of hospitality and assistance which research has also revealed. Such everyday acts of conviviality are offered by individuals who seek to welcome and accommodate newcomers to their community. They find ways to extend boundaries of inclusion and seek to overcome injustices that persist. This is in a context where migrants are often fully documented and have full rights to participate fully in society ${ }^{7}$. The research to date is fragmented, and based on relatively ad hoc studies, but indicates how civil society organisations (charities and church-based groups) provide basic meals and short-term shelter for many (McAreavey, 2012). These connections have been shown to create opportunities for positive interaction in the broader community, and for engagement in wider local networks.

Welfare state retrenchment and rural services. The UK welfare state has become more similar to that of the US. People not working are seen as failures, and individuals need to prove that they are entitled to use a service. Despite the various reforms and government rhetoric of reducing inequalities, they have been steadily rising in the UK: child poverty and people in precarious employment are amongst the highest in the EU; both are on the rise. Meanwhile, in the US state by state autonomy means that "place" has heightened importance as individual state actions have resulted in very different opportunities and outcomes in different parts of the nation.

In both nations, privatisation is a master trend that accompanies state withdrawal from social welfare. Whether it is income maintenance, education or health care, both the UK and US national governments have devolved more responsibility to local governments and/or to private business. Rural people are particularly affected by this trend because rural communities, especially in the US, tend to have narrower resource bases and less institutional capacity. The present UK Conservative government's 'hollowing out' of the state has resulted in the privatisation of some services while others have been outsourced to private companies, many of which attract attention due to various ineptitudes in service provision within prisons, security services and housing (Harris, 2018). Similar situations were experienced in the US. New Deal social programmes have been undermined and service responsibilities have been passed down to states without sufficient financial resources to maintain service levels. As a result, many previous public services have been privatised, often making them unaffordable for lower income residents (Warner, 2003). Parallel to the slimming of the state, in the UK social actors are increasingly implicated in policing access to a range of services in a manner similar to that found in the US (Wells, 2004, Varsanyi, 2011). Individuals at front desks, landlords, doctors, universities and many others have become agents of the state, raising concerns of equality and rights ${ }^{8}$.

In contrast to the growing similarity between UK and US "welfare to work" type income maintenance programmes, education programmes in the US and UK continue to be administered in a strikingly different manner. Theoretically, to the extent that education is the doorway to well-paying jobs and economic security across one's life course, this should tend to equalise opportunity across class, race and rural-urban residence groups in the UK. However, while the UK and US systems differ greatly, some scholars believe that this difference seems to be converging, and not in a good way. While education has traditionally been closely planned, regulated and funded by the UK national government this is shifting and reforms have become more similar to the US where states and local communities have major responsibility. According to the Centre for Budget Priorities, "on average, $47 \%$ of school revenues in the United States come from state funds. Local governments provide another $45 \%$, mostly from property taxes; the rest comes from the federal government." (Leachman et al., 2017). Moreover, state funding has declined in many states since the 2008 recession. In Tennessee, with an $18 \%$ poverty rate in 2014 , total per pupil spending was $\$ 8242$ (6th lowest of all states), while per pupil spending in Rhode Island was $\$ 13,815$ (9th highest) (Sauter, Hess and Froelich, 2014.) Accordingly, the quality of education varies significantly across the 50 US states, and across localities within states. If one is unlucky enough to live in a rural part of a low effort state, the deficit can be significant, and can contribute to significant underinvestment in education and resulting loss of human capital. In fact, rural communities have the worst of both worlds. Better prepared students, regardless of the strength of their local schools, tend to migrate away after graduation while poorer students, those who might perform better in more strongly supported schools elsewhere, generally stay in town where they are often under-employed (Carr and Kefalas, 2009).

During the 1980s and 1990s 'market mechanisms' were introduced into the UK education systems, originally through the 1988 Education Reform Act. One of the outcomes of this was 
an increase in parental choice and the introduction of a degree of budgetary autonomy (Machin and Vignoles, 2005). In addition to a core grant from the state, local authorities can raise local revenue through a Fair Funding formula. The marketization of education continues; for example, the Academies Act (2010) openly embraces profit making within education. Some schools have been allowed to take full control of budgets received from central government and are linked to student enrolment and other factors, including the numbers of pupils who are entitled to free lunches. The erosion of a direct relationship between local government and schools has particular implications for rural schools, given that they tend to be expensive to run, as it places them firmly in the gaze of cash strapped policymakers who may wish to centralise services. The struggle to retain rural schools remains an important issue for UK rural communities.

Of course, one of the most obvious differences between the UK and US welfare states is that the UK has universal single payer healthcare, while the US has a pay for service system with some special cut outs for specific populations such as the low income, elderly and disabled (e.g., Medicare and Medicaid). In the past employers provided many employees with health insurance, this benefit has diminished dramatically in recent decades. In 2010 the US Congress passed the Affordable Care Act (aka Obamacare). While not universal health care, the programme provided access to health insurance for tens of millions of previously uninsured persons. In addition, states were encouraged to expand Medicaid which enhanced health care access for the low income, elderly and disabled persons, including many in rural areas. Many states agreed to this expansion, but many, especially southern, rural and conservative states did not. The critical importance of Medicaid expansion for vulnerable populations, including those in rural areas can be judged by the facts: $48 \%$ of all US births were covered by Medicaid in 2018, and about $65 \%$ of nursing home residents are supported primarily by Medicaid ${ }^{9}$. Conservatives have been trying to kill Obamacare ever since its passage. The major opposition seems to be a claim of federal overreach, once again highlighting the importance of America's federalist legacy on its contemporary social welfare system. So far attempts to abolish Obamacare have failed, but the 2017 US income tax law does away with the penalty for not having health insurance. Accordingly, the incentive for younger and healthier people to have coverage is diminished which could result in huge increases in premiums for remaining policy holders.

Austerity politics have changed the welfare landscape in the UK, including impacting significantly on health services. Dogmatically pursued in the UK by George Osborne under David Cameron's government, they consisted mainly of cutting public spending in an era of recession; directly contradicting Keynesian wisdom (Krugman, 2015). The reduction in the overall size of UK government is visible across society at different scales of government from the national (e.g., Welfare Reform Act of 2012) to the local (e.g., decline or removal of local services including libraries, leisure centres and adult social care) and is felt right across education, housing and health. Sparse public transport heightens these cuts in rural areas. One of the reforms being mooted at the local level is a shift from the current redistributive funding model to a more autonomous approach, meaning that poorer areas will be unable to raise as many funds as more prosperous areas. This proposed shift towards local autonomy is more similar to the US approach, and the implications for rural communities remains to be seen.

Moving forward. Inequality and poverty are important topics for continued rural research in both the UK and US. We have shown above how the US and UK situations and welfare systems are both similar and different in many ways. As we argued at the paper's very beginning, we think a methodologically harmonised comparative analysis of rural poverty and inequality in the UK and US is problematic. However, we believe that placing the UK and US in parallel can provide important evidence-based insights about the structural forces that produce and reproduce poverty and rural inequality in rural areas of the respective nations, as well as about policies to ameliorate these problematic conditions (Lowe, 2012). We identify a number of ideas for moving this agenda forward. We recommend that rural scholars continue to examine both overriding and more specific questions about rural poverty and inequality. At the most general level, two overriding questions, one micro-level and one macro-level, merit additional research in both the US and UK. We recommend that researchers:

- Micro-level: Determine the impact of place of residence on the likelihood of individual and household-level poverty, the duration of poverty spells, and the likelihood of poverty exit and entrance once the impacts of other co-variates of poverty have been accounted for.

- Macro-level: Examine the social and economic dynamics that contribute to inter-place differences in poverty rates and/or levels of inequality. Does rural-urban location have a persistent impact on poverty and/or inequality rates once demographic and economic composition and change have been controlled?

We also recommend that researchers examine a number of more specific aspects of rural poverty and inequality in both the UK and US. They should:

- Examine the relationships between poverty and inequality using a multi-level, mixed methods approach that merges statistical analysis with grounded studies of the lived experiences of poor persons living in areas with varying degrees of inequality.

- Focus on persons and places in deep and persistent poverty paying special attention to persons at high risk of poverty such as children, elders, disabled and migrants. We recommend that researchers examine the impact of living in differing types of spatial context on the likelihood of being in deep and persistent poverty, and of entering and exiting this status.

- Examine the relationship between lack of income and the various dimensions of social exclusion. Is lack of income a determinant of these various forms of exclusion, or is it a consequence? No clear answer has arisen from previous work on whether the level of income inequality or the poverty rate causes social exclusion even though many think tanks and charities, such as the Joseph Rowntree Foundation, have for a long-time supported research on the different forms of exclusion and their relationship to low income.

- Conduct additional research to determine why many eligible persons do not utilise welfare services for which they are eligible. Does the degree of utilisation of similar programmes differ between the UK and US? If so why? If not, what factors are associated with programme participation, or lack thereof?

- Study the anti-poverty impact of rural proofing in the UK and its applicability to the US. We recommend that rural researchers attempt to develop a similar concept that could be deployed in the US ${ }^{10}$.

- Study whether segmenting poverty into its symptomatic components is an effective way of addressing poverty. In addition to securing attention from the public, does this issuespecific approach set different constituencies, say housing versus food security, against each other in a zero sum 
competition? Research in the US and UK might examine the effectiveness of the issue-specific approach in addressing the basic causes and consequences of poverty, and its amelioration.

- Examine why the fate of legal migrant workers in UK agricultural industries is similar to the fate of illegal undocumented migrant workers in the US. Why does one set of workers who are legal end up experiencing such inequality? What will happen with Brexit when these workers will potentially become illegal migrant workers?

- Examine the implications of welfare reform on rural communities as welfare-to-work and market solutions are increasingly, but often differently, applied to the US and UK welfare regimes.

The questions posed above are inherently inter-disciplinary, as is the entire field of rural studies (Shucksmith and Brown, 2016). While particular disciplines such as Rural Sociology, Agricultural Economics, Rural Geography and Land Economy have focused on certain aspects of rural population, economy and environment, the broader trend is much more integrative across disciplines, or at least we propose it should be. In 2006, in recognition of the essential interdisciplinary nature of rural studies, a diverse group of rural-oriented social scientists in the UK and US established an international, interdisciplinary research network focused on rural transformations and rural policies in the global North. The network, initially called QUCAN, was comprised of scholars from Queens University in Belfast, the University of Highlands and Islands, Cornell University, Aberdeen University, and Newcastle University. While UHI has now dropped out, the network, since renamed the Trans-Atlantic Rural Research Network (TARRN), has been joined by Aberystwyth and Penn State Universities, and is going strong. As Shortall and Brown have commented, "Dedicated communities of scholars regularly enrich each other by testing the merit of diverse methodologies, conceptual frameworks and institutional arrangements" (2019, p. 6). TARRN, hence, provides an infrastructure for international, interdisciplinary comparative scholarship that we contend enhances the ability to recognise the universal in the particular, while identifying similarities and differences in the determinants and consequences of rural deprivation in the UK and US.

\section{Data availability}

All data analysed or generated is included in the paper.

Received: 9 May 2019; Accepted: 24 September 2019;

Published online: 15 October 2019

\section{Notes}

1 In contrast, the Cross-national Data Centre in Luxembourg acquires datasets with income, wealth, employment, and demographic data from many high-income and middle-income countries, harmonises them to enable cross-national comparisons, and makes them publicly available in two databases. Scholars from around the world use these data to conduct cross-national comparative research on socio-economic outcomes and on the institutional factors that shape those outcomes. In contrast, we question the conceptual and cultural comparability of data such as these.

2 High poverty was indicated as 15.5 pct. or higher, while high inequality was indicated as a Gini of 0.43 or higher during 2010-2014.

3 Increasingly the measurement of poverty in the UK recognises the structural and relational aspects such as early years, problem debt, homelessness and youth conflict (Francis-Devine et al., 2019)

4 It is possible to use individual or household level data to make inferences about population-level differences in inequality. For example, Hertz and Silva (2019) used household data to compute Gini indices for metropolitan and nonmetropolitan populations in order to examine differences in the degree of inequality between metropolitan and nonmetropolitan areas over time. However the focus is still on inter-population difference, e.g., it is a macro level question.

5 The suite of reforms continued the Income Support and Job Seekers Allowance in addition to a national minimum wage, a working family tax credit, incapacity benefits, a pension credit among other programmes.

6 We have chosen not to discuss health care programmes in this paper such as the UK's NHS and Medicare and Medicaid in the US. This extremely complicated issue could be a chapter of its own.

7 Other issues arise for undocumented workers.

8 For instance, The National Health Service (2017) (Charges to overseas Visitors) compel healthcare staff to check a patient's immigration status so that they can determine whether or not an up-front charge should be made. If the patient's status cannot be determined, the doctor then needs to decide if treatment is immediately necessary, urgent or non-urgent, these three categories influencing the payment required. This mirrors the approach in the US such as the Illegal Immigration Relief Act enacted in the City of Hazleton in Pennsylvania where landlords may be fined if they rent apartments to undocumented migrants (Varsanyi, 2011)

9 Medicaid pays for $45 \%$ of the total nursing home bill.

10 Rural proofing is an assessment by policymakers of the effects of their policies on rural areas. The UK's rural proofing policy is ironic, given the, often contradictory, statistical record of rural disadvantage in the UK (Shortall and Alston, 2016). Shortall and Alston argue that rural proofing is problematic because it is unclear what rural problem it is designed to solve. In the US, in contrast, all of the income-related forms of poverty and inequality (child poverty, disposable income, etc.) are generally higher in rural areas, hence proofing would seem clearly justified. Shortall and Alston's (2016) research shows the serious shortcomings of rural proofing's ability to influence policy. They conclude that "reinvigorating rural proofing is likely to be a key element of the relevant ministers' election strategies." We recommend that rural researchers further examine the efficacy of rural proofing, and its impact on rural policy.

\section{References}

Allison P (1978) Measures of inequality. Am Sociol Rev 43:865-880

Barnard H, Collingwood A, Leese D, Wenham A, Drake B, Smith E, Kumar A (2018) UK Poverty 2018. Joseph Rowntree Foundation, York. https://www.jrf. org.uk/report/uk-poverty-2018. Accessed 19 Sep 2019

Binelli C, Loveless M, Whitefield S (2015) What is social inequality and why does it matter? World Development 70:239-248

Bock B, Kovaćs K, Shucksmith M (2014) Changing social inequalities, patterns of inequality and exclusion. In: Copus AK, De Lima P (eds) Territorial cohesion in rural Europe: the relational turn on development. Routledge, Oxon, pp 193-211

Brewer M, Shepherd A (2004) Has labour made work pay? Joseph Rowntree Foundation, York

Byrne D (1999) Social exclusion. Open University Press, Buckingham

Cappellari L, Jenkins S (2014) The dynamics of social assistance benefit receipt in Britain. In: Carcillo S, Immervoll H, Jenkins S, Königs S (eds) Safety nets and benefit dependence. Emerald, London, pp 41-79

Carr P, Kefalas M (2009) Hollowing out the middle: the rural brain drain and what it means for rural America. Beacon Press, Boston

Center for Budget Priorities (2017) State temporary assistance for needy families programs do not provide adequate safety net for poor families. https://www cbpp.org/state-temporary-assistance-for-needy-families-programs-do-notprovide-adequate-safety-net-for-poor. Accessed 26 April 2019

Chapman P, Phimister E, Shucksmith M, Upward R, Vera-Toscano E (1998) Poverty and exclusion in rural Britain: the dynamics of low income and employment. Joseph Rowntree Foundation, York

Cheetham M, Moffatt S, Addison M, Wiseman A (2019) Impact of universal credit in North East England: a and support staff. BMJ Open 9:e029611. https://doi. org/10.1136/bmjopen-2019-029611

Chetty RJ, Friedman JN, Hendren N, Jones MR, Porter SR (2018) The opportunity atlas: mapping the childhood roots of social mobility. NBER Working Paper No. 25147. https://www.nber.org/papers/w25147. Accessed 17 Sep 2019

Doyle C (2018) Migration, planning and superdiversity in rural Northern Ireland and England. Unpublished PhD thesis. Queen's University Belfast

Duncan C (2014) Worlds apart (second ed). Yale University Press, New Haven

Duncan C, Lamborghini N (1994) Poverty and social context in remote rural communities. Rural Soc 61:437-461

De Lima P, Parra PA, Pfeffer MJ (2012) Conceptualizing COntemporary Immigrant Integration in the Rural United States and United Kingdom. In: Shucksmith M, Brown DL, Shortall S, Vergunst J, Warner M (eds) Rural transformations and rural policies in the US and UK. Routledge, London, pp 79-99

Fahey T (2010) Poverty and the two concepts of relative deprivation. UCD School of Applied Social Science Working paper series 2010. WP10/1 July 2010. University College Dublin, Dublin

Findlay A, McCollum D (2013) Recruitment and employment regimes: migrant labour channels in the UK's rural agribusiness sector, from accession to recession. J Rural Stud 30:10-19 
Fitchen J (1991) Endangered spaces, enduring places: change, identity and survival in rural America. Westview, Boulder

Francis-Devine B, Booth L, McGuinness F (2019) Poverty in the UK. House of Commons Library, Briefing Paper 7096. https://researchbriefings.files. parliament.uk/documents/SN07096/SN07096.pdf. Accessed 17 Sep 2019

Gough I (2008) European welfare states: explanations and lessons for developing Countries. In: Dani AA, Harjan de H (eds) Inclusive states: social policy and structural inequalities. World Bank Publications, Washington, USA, pp 3-38

Gray RM (2011) Entropy and information theory. Springer, New York, London

Harris J (2018) Rats, mould and broken furniture: the scandal of the UK's refugee housing. The Guardian https://www.theguardian.com/society/2018/jan/10/ rats-mould-and-broken-furniture-the-scandal-of-the-uks-refugeehousingchaos. Accessed 26 April 2019

Hertz T, Silva A (2019) Rurality and Income Inequality in the United States, 1975-2015. Rural Sociology

Hickman P, Kemp PA, Reeve K, Wilson I (2017) The impact of the direct payment of housing benefit: evidence from Great Britain. Housing Stud 32:1105-1126

Jensen L (1994) Employment hardship and rural minorities: theory, research and policy. Rev Black Political Econ 22(4):125-144

Johnson K, Lichter DT (2016) Diverging demography: hispanic and non-hispanic contributions to U.S. population redistribution and diversity. Population Res Policy Rev 35:705-725

Kandel W, Parrado E (2006) Rural hispanic growth: public policy impacts in nonmetro Counties. In: Kandel W, Brown DL (eds) Population change and rural society. Springer, Dordrecht, pp 155-176

Kritz M, Gurak D, Lee M (2013) Foreign-born out-migration from new destinations: onward or back to the enclave? Soc Sci Res 42:527-546

Krugman P (2015) The case for cuts was a lie. Why does Britain still believe it? The austerity delusion. The Long Read. The Guardian. https://www.theguardian. com/business/ng-interactive/2015/apr/29/the-austerity-delusion. Accessed 29 April 2015

Kyambi S, Kay R, Boswell C, Taggart K, Porteous H (2018) Choices ahead: approaches to lower skilled labour migration after Brexit. Project report, centre on constitutional change. University of Edinburgh, Edinburgh

Lambie-Mumford H (2015) Addressing food poverty in the UK: charity, rights and welfare. Speri Paper No, 18, ISSN 2052-000X. http://speri.dept.shef.ac.uk/wpcontent/uploads/2015/02/SPERI-Paper-18-food-poverty-in-the-UK.pdf. Accessed 26 April 2019

Leachman, M, Masterson K, Figueroa E (2017) A punishing decade for school funding. https://www.cbpp.org/research/state-budget-and-tax/a-punishingdecade-for-school-funding. Accessed 26 April 2019

Lichter DT, Johnson KM (2006) Emerging rural settlement patterns and the geographic redistribution of America's new immigrants. Rural Sociol 71 (1):109-131

Lichter DT, Parisi D, Taquino MC (2018) White integration or segregation? The racial and ethnic transformation of rural and small town America. City Community 17(3):702-719

Lister R (2004) Poverty and social justice: recognition and respect. Third Bevan Foundation Annual Lecture, 24th June 2004. https://www.bevanfoundation. org/wp-content/uploads/2011/12/Ruth-Lister-2004.pdf. Accessed 19 Sep 2019

Lobao LM, Hooks G, Tickamyer AR (eds) (2007) The sociology of spatial inequality. State University of New York Press, Albany

Lowe $P$ (2012) The agency of rural research in comparative context. In: Shucksmith M, Brown DL, Shortall S, Vergunst J, Warner M (2012) (eds) Rural transformations and rural policies in the US and UK. Routledge, New York, pp $18-38$

Mather M, Jarosz B (2016) Population reference bureau: Washington, DC. https:// www.prb.org/poverty-and-inequality-us-counties/\#. Accessed 26 April 2019

Machin S, Vignoles A (2005) Education Policy in the UK. Centre for the Economics of Education. London School of Economics, London

Mathieson J, Popay J, Enoch E, Escorel S, Hernandez M, Johnston H, Rispel L (2008) Social exclusion: meaning, measurement and experience and links to health inequalities. A review of literature. WHO Social Exclusion Knowledge Network Background Paper 1. Institute for Health Research Lancaster University, Lancaster

May T (2017) The shared society: Prime Minister's speech at the Charity Commission annual meeting, 9th January 2017. https://www.gov.uk/government/ speeches/the-shared-society-prime-ministers-speech-at-the-charitycommission-annual-meeting. Accessed 26 April 2019

McAreavey R (2012) Resistance or resilience? tracing the pathway of recent arrivals to a 'new' rural destination. Sociol Ruralis 52(4):488-507

McAreavey R (2017a) New immigration destinations: migrating to rural and peripheral areas. Routledge, London

McAreavey R (2017b) Migrant identities in a new immigration destination: revealing the limitations of the 'hard working' migrant identity. Population Space Place 23(6):1-14

McAreavey R (2019) Unravelling the complexities of poverty in a New Immigration Destination: migrants in Northern Ireland. In: Gaisbauer HP, Schweiger
G, Sedmak C (eds) Absolute poverty in Europe: interdisciplinary perspectives on a hidden phenomenon. The Policy Press, Bristol, pp 211-228

McConnell ED, Miraftab F (2009) Sundown town to Mexican town: newcomers, old timers, and housing in small town America. Rural Sociol 74(4):605-629

Middlemiss L (2017) A critical analysis of the new politics of fuel poverty in England. Crit Soc Policy 37(3):425-443

Milbourne P (2004) Rural poverty: marginalisation and exclusion in Britain and the United States. Routledge, London

Mishra R (1984) The welfare State in crisis: social thought and social change. Wheatsheaf, Brighton

Moffatt S, Glasgow N (2009) How useful is the concept of social exclusion when applied to older rural people in the UK and US? Region Stud 43:1291-1303

Monnat S, Rigg K (2016) Examining rural/urban differences in prescription opioid misuse among U.S. adolescents. J Rural Health 32(2):204-218

Moore H (2019) Perceptions of Eastern European migrants in an English village: the role of the rural place image. J Ethnic Migration Stud 1-17. https://doi. org/10.1080/1369183X.2019.1623016

Nolan B, Whelan CT (2007) On the multidimensionality of poverty and social exclusion. In: Micklewright J, Jenkins S (eds) Poverty and inequality: new directions. Oxford University Press, Oxford, pp 146-165

Nolan L, Waldfogel J, Wimer C (2017) Long-term trends in rural and urban poverty: new insights using a historical supplemental poverty measure. Annals Am Acad Pol Soc Sci 672:123-142

O’Hara M (2015) Austerity bites. Policy Press, Bristol

Platt L (2007) Poverty and ethnicity in the UK. Joseph Rowntree Foundation, York

Pfeffer MJ, Parra PA (2009) Strong ties, weak ties, and human capital: latino immigrant employment outside of the enclave. Rural Sociol 74:241-269

President's National Advisory Commission On Rural Poverty (1967) The people left behind. US Government Printing House, Washington, DC

Purdam K, Garratt EA, Esmail A (2016) Hungry? food insecurity, social stigma and embarrassment in the UK. Sociology 50(6):1072-1088

Rural Sociological Society (1993) Persistent poverty in rural America. Westview Press, Boulder

Rank M, Hirschl T (1999) The likelihood of poverty across the American adult life span. Social Work 44(3):201-216

Reed H, Portes J (2018) The cumulative impact on living standards of public spending changes Research Report 120: Equality and Human Rights Commission. https:// www.equalityhumanrights.com/en/publication-download/cumulative-impactliving-standards-public-spending-changes. Accessed 18 Sep 2019

Sauter M, Hess A, Froelich T (2014) States with the most (and Least) government benefits. 24/7 Wall Street. https://247wallst.com/special-report/2014/01/24/ states-doling-out-the-best-and-worst-benefits/5/. Accessed 26 April 2019

Sherman J (2014) Rural Poverty, The great recession, rising unemployment, and the underutilized safety net In: Bailey C, Jensen L, Ranson E (eds) Rural America in a globalizing world. University of West Virginia Press, Morgantown, pp 523-539

Sherman J (2009) Those who work, those who don't: poverty, mortality and family in Rural America. University of Minnesota Press, Minneapolis

Shortall S, Warner M (2012) Rural transformations: conceptual and policy issues. In: Shucksmith M, Brown DL, Shortall S, Vergunst J, Warner M (2012) (eds) Rural transformations and rural policies in the US and UK. Routledge, New York, pp 3-17

Shortall S, Alston M (2016) To rural proof or not to rural proof: a comparative analysis. Pol Policy 44(2):35-55

Shortall S, Brown DL (2019) Thinking about rural inequalities as a cross-national research project. Guest editorial for special issue on rural inequalities. J Rural Stud 68:213-221

Shucksmith M (2012) Class, power and inequality in rural areas: beyond social exclusion? Sociol Rural 52(4):377-397

Shucksmith M, Chapman P, Clark G (1993) Disadvantage in rural Scotland: how is it experienced and how can it be tackled? Rural Forum Scotland, Perth

Shucksmith M, Cameron S, Merridew T, Pilcher F (2009) Urban-rural differences in quality of life across the European Union. Regional Stud 43(10):1275-1289

Shucksmith M, Schafft K (2012) Rural poverty and social exclusion in the United States and the United Kingdom. In: Shucksmith M, Brown DL, Shortall S, Vergunst J, Warner (eds) Rural transformations and rural policies in the US and UK. Routledge, New York, pp 100-116

Shucksmith M, Brown DL (2016) Framing Rural studies in the global north. In Shucksmith M, Brown DL (eds) Routledge international handbook of rural studies. Routledge, London, pp 1-26

Shucksmith M, Brown DL, Shortall S, Vergunst J, Warner M (2012) (eds) Rural transformations and rural policies in the US and UK. Routledge, New York

Sibley D (1995) Geographies of exclusion. Routledge, London

Smith N, Davis A, Hirsch D, (2010) A minimum income standard for rural households. Commission for Rural Communities and Joseph Rowntree Foundation, London

Stevens A (1999) Climbing out of poverty, falling back in: measuring the persistence of poverty over multiple spells. J Human Resources 34(3):557-588 
The National Health Service (Charges to Overseas Visitors) (Amendment) Regulations (2017) Available at http://www.legislation.gov.uk/uksi/2017/756/ contents/made, Accessed 04 Oct 2019

Therborn G (1984) Classes and states: welfare state developments 1881-1981. Stud Pol Econ 14(1):7-41

Thiede B, Butler J, Brown DL, Jensen L (2019) Income Inequality Across the Urban-Rural Continuum, 1970-2016. Presented to the Population Association of America, Austin, Texas

Tsimbos C, Kalogirou S, Verropoulou G (2014) Estimating spatial differentials in life expectancy in Greece at local authority level. Population, Space and Place 20(7):646-663

Toynbee P, Walker D (2011) The verdict: did labour change Britain? Granta, London

Urban Institute (2019) State and Local Finance Initiative Backgrounder. https:// www.urban.org/policy-centers/cross-center-initiatives/state-and-localfinance-initiative/state-and-local-backgrounders/public-welfare-expenditures. Accessed 01 Sep 2019

United States Department of Agriculture (2018) Rural America at a glance: 2018 edition. https://www.ers.usda.gov/webdocs/publications/90556/eib-200.pdf, Accessed 01 Sep 2019

Van Heuvelen T (2018) Recovering the missing middle: a mesocomparative analysis of within-group inequality, 1970-2011. Am J Soc 123(4): 1064-1116

Varsanyi MW (2011) Neoliberalism and nativism: local anti-immigrant policy activism and an emerging politics of scale. Int J Urban Regional Res 35 (2):295-311

Vera-Toscano E, Shucksmith M, Brown DL (2019) The dynamics of low income in Rural Britain 1991-2008: did rural poverty improve under new labour? Presented to the European Society of Rural Sociology, Trondheim, Norway and the Rural Sociological Society, Richmond

Wallerstein I (1996) Open the social sciences. Report of the Gulbenkian Commission on the Restructuring of the Social Sciences. Stanford University Press, Stanford

Warner M (2003) Competition, cooperation and local governance In: Brown DL, Swanson L (eds) Challenges for rural America in the twenty-first century. Penn State Press, University Park, pp 252-261

Wells M (2004) The grassroots reconfiguration of U.S. immigration policy. Int Migration Rev 38(4):1308-1347
Woodhouse J (2015) The voluntary sector and big society. House of commons briefing paper number 5883, 13 August 2015. https://publications. parliament.uk/pa/cm201012/cmselect/cmpubadm/902/902.pdf. Accessed 26 April 2019

\section{Acknowledgements}

An earlier version of this paper was presented at the annual Trans-Atlantic Rural Research Network meeting in Cornell University in 2018. The authors are grateful to participants at that workshop for their comments.

\section{Competing interests}

The authors declare no competing interests.

\section{Additional information}

Correspondence and requests for materials should be addressed to R.M.

Reprints and permission information is available at http://www.nature.com/reprints

Publisher's note Springer Nature remains neutral with regard to jurisdictional claims in published maps and institutional affiliations.

(c) Open Access This article is licensed under a Creative Commons Attribution 4.0 International License, which permits use, sharing, adaptation, distribution and reproduction in any medium or format, as long as you give appropriate credit to the original author(s) and the source, provide a link to the Creative Commons license, and indicate if changes were made. The images or other third party material in this article are included in the article's Creative Commons license, unless indicated otherwise in a credit line to the material. If material is not included in the article's Creative Commons license and your intended use is not permitted by statutory regulation or exceeds the permitted use, you will need to obtain permission directly from the copyright holder. To view a copy of this license, visit http://creativecommons.org/ licenses/by/4.0/.

(c) The Author(s) 2019 